\title{
Introspective Effect of E-Learning over T-Learning - An Analytical Report
}

\author{
A. Senthil Karthick Kumar \\ Department of Computer Applications, \\ Nehru Institute of Information \\ Technology and Management \\ Coimbatore, India
}

\author{
A. M .J. Md. Zubair Rahman \\ Al-Ameen Engineering College, \\ Erode, Tamilnadu, India
}

\begin{abstract}
It is imperative that education is the backbone of any economy. It strengthens the various aspects like science and technology, management, administration and decision making of any nation. After the introduction of LPG in 1991, industry has taken its reforms in several aspects. Even it has not spared the educational industry. In the recent past, the Educational Industry has seen a tremendous change in the system on the whole. The technological advancements and innovations have created an entirely new system. Yes, the learning system has changed from the Traditional Learning (T-Learning) system to Electronic Learning (E-Learning) system. In this article the researcher would like to discuss on the effectiveness of the students learning system, with a comparative study on the learning methods i.e. ELearning and T-Learning. This study has been carried out on the basis of student's preference. A structured questionnaire has been circulated to collect data from 150 students, who pursue post graduate programs from 15 Colleges. Out of which 132 questionnaires were received back. From the study the pedagogy will be framed to improve the efficiency of the most preferred system which intern will change the entire learning practices of the young and future generations.
\end{abstract}

\section{Introduction}

It is high time that we have to rethink about how to improve the current higher educational system, in order to strengthen the competitiveness of graduates by using any effective educational thoughts, techniques and advanced technology resources, especially computer and internet resources. [1]. Morgan keegan's investment analysis team deems elearning as a technology that fully leverages the distributive power of the internet and encourages investors to consider the "e" in e-learning to represent "effective" [2]. It's imperative that Educational system is surviving for decades, and still, there is no diminishing factor on any ground in this system has occurred so far. The teaching methodology and mode has been changed and updated, taken twists and turns to inculcate various practices to improve the learner's abilities. In this paper the researcher have focused more on the mining of data in educational sector, where a number of thoughts and perception has been made to make this industry to survive and grow in a massive way. The word illiteracy needs to be removed from the global context. In such a forum, does the CRM (Class Room Management) really focuses on the students or learners community? Where and what kind of desired things the learners are looking for? Need to be indentifying in the perspective of ELearning system. How can this help the educational society to consider and project the required and desired needs of learner's? When comparative analysis is done on Traditional learning \& Elearning, most likely all will be in favour of electronic learning system as there are a lot of advantages when compared to T-Learning. But the fact as per general public opinion is instructor credential can be enhanced by using technologies but the credit is always based on the factor of transferring the expert knowledge one-on-one in the class room. The modern-day technologies allow us to develop a quality multimedia and interactive contents as well as systems able to simulate such complex procedure as the work of teacher, thus we can say that the adaptive form of e-learning aims to substitute an experienced teacher in the widest possible extent [3]. When comparing learning an identical course in traditional framework to a computer mediated learning framework, students have expressed higher satisfaction from the computer mediated learning, and rated the learning as more effective than in the traditional framework. In other studies too, it was argued that computer mediated or online learning is more effective and interactive [4]. Assessing and measuring the efficiency and effectiveness of teaching performance is an ongoing process, so it is a crucial issue in higher education. Assessing performance helps faculty members think about what results and skills that they want their students to acquire. It also validates expectations of learning outcomes and maps such outcomes with institution's vision, mission, and objectives. Moreover assessment supports continence communication, feedback and dialogue about 
performance teaching [5]. The form of traditional learning system is so far factorizing the community. Traditional learning mainly focuses on the following criteria: Expert Knowledge, Communication, Knowledge Sharing, Individual Student Concentration (ISC) and so on. On the other side, the heavy competitiveness required in the student's community on the basis of communication spreading, which creates an awareness of social media and social networks e.g. face book, Twitter, Linked in. when we analysis the statistical report of these sites which the researcher mentioned above has grown in tremendous way due to the knowledge sharing. E-learning systems are becoming technologically sophisticated and, complicated with regard to training management or course management [6]. Their use doesn't match with traditional modes of teaching and learning and much care needs to be taken when considering the use of E-learning in educational institutions [7]. These findings are in accordance with Beebe, Vonderwell and Boboc's (2010), who state that the instructor's role in e-learning requires rethinking and reconstructing of assessment practices [8]. Feldman (1997) believes that instruments of assessing teaching should be multidimensional because teaching and instruction in higher education consist of various components [9]. Designing multidimensional and comprehensive instruments for assessing teaching provides valuable feedback to instructors about their teaching quality. Moreover, it is crucial for faculty members to understand how to use such feedback, so as to address their students concerns and needs.

\section{The Study}

Change is difficult but it is probable that the rapid development and implementation of new technologies and social changes make change in educational provision inevitable [10]. E-learning can be understood as an educational process, using information and communication technologies to create training, to distribute learning content, communication between students and teachers and for management of studies [11], [12]. E-learning courses are now primarily web applications, designed to enable distance form of education and also taking the required test [11]. The current study addresses the four major research questions: A) Perspectives of T-Learning in accordance to the scenario of Post graduate students in Coimbatore, India (specific region oriented). B) The perspective and awareness beheld with post graduate learners society regarding E-Learning, how it can be explored and utilized. C) So far in which way they have practiced the learning system and got benefited. D) How they assess the instructor in both models. In this study we tried to figure out the impact of the instructor's ability and efficiency inside the class rooms and if the instructor performance is not satisfactory, special attention like (Faculty Development Programs, Quality Improvement Programs) are provided to them internally to improve it. The questionnaire was adopted from many instruments that examine the student's attitudes, perceptions and perspectives, as Al-Karin et al., Hussein constructs validity and content validity of the questionnaire was ensured [13], [14]. The classical teaching main element is the lecture in which the teacher explains, gives examples, shows calculations, etc. The accent was put on the oral communication, which was supported by on-line hand written messages using the blackboard and chalk [15]. There are also different roles for the learners in education system like [16]:

1. Learner as a searching force of information, leader and evaluator

2. Learner as a thinker, critic, analyzer and selector of information and suitable technology

3. Learner as a knowledge producer by the use of new resources and technologies

4. Learner as a messenger by the use of new resources and technologies

\section{Learner as an educational technologist}

\section{Learner as a responsible citizen in technology age}

The goal of the online component of the course consideration in this study, was to extend the boundaries of the classroom in order to increase participation, improve the quality, enhance the interaction with and between students and instructor, and address student's needs more accurately [17] However, concerning the future of e-learning, participants view a future tendency towards the provision of full online degrees, yet, they are skeptical; stating that e-learning setting will not completely replace the traditional educational setting [18]. With a team of experts in pedagogy, psychology and ICT education we have been working on a new model of personalized e-learning education, providing the students with tailored courses and instruction within an electronic environment. This model consider three main subjects, modules of educational interaction: a student, a teacher and an environment, and we are dealing with all of them to achieve the final and complex solution [19]. Today with regard to variety of societies, human beings, innovations and their interests, it is necessary to have variety of learning 
methods. But this may need a new framework of teaching with enough reflection as well. Learning is not limited only to what has been performed in classroom [20]. The main issues being focused on are related to learning and its transferability, and tied to the need for stronger interaction between research and didactics [21], [22] Based on the measures given by Bidarian 2011, research has been classified and observation were made on researchers and learners learning system. All these collection of data from the respondents has incorporated into our research work for doing a better service in our educational sector in means of perspective of our learner's society.

\subsection{Perspectives of $T$-Learning in accordance to the scenario of Post graduate students in Coimbatore, India (specific region oriented)}

The main advantage in T-Learning is that student's attitude and their behavioral mode can be assessed by the instructors very easily. In that context the instructor can handle the students in such a way that, they can cooperate with the system at ease. This is supported by Tuncay et.al, that "Now a day, education environments have two forms. These are traditional and virtual education environments. In both environments, one of the important problems is habit analysis and evaluation. In traditional education system, habit analysis is done easily through observation techniques, whereas in virtual one analyzing students attitudes and habits is a significant problem [23]."

\subsection{The perspective and awareness beheld with post graduate learners society regarding E-Learning, how it can be explored and utilized}

E-Learning, though a term spread across the world long back, reached the targeted region? A study has been conducted to understand the awareness level in the perspective of various factors influences and controls. The results are discussed in the analysis. As per the previous study conducted by Senthil Karthick kumar, Zubair Rahman and Moses Daniel [24] yes, due to the knowledge transactions, independency and self learning of the learners will tend to explore their information which they receive from the learning system. This is because the most principle of teaching / learning process is finding some scientific skills, self guidance, cooperative learning, providing of active and transaction learning process, involvement in learning process, partnership in knowledge production and project-based educational activities [20-25-26]. Learning style is one of the commonly studied individual properties. There are many learning style approaches over various dimensions in literature [27-28]. Many educational institutions try to build their own internal tools to develop and deliver e-learning contents. They spent too much time to develop courses but later on could not re-use or could not transfer these courses to new e-learning systems [29].

\subsection{So far in which way they have practiced the learning system and got benefited}

Coimbatore the other way called as textile city has become an educational hub, flooded with more than 120 colleges and around 174 schools is known place for traditional learning system. The students where spread across the whole world who were benefited much from the traditional learning environment. With the recent trend with increasing population requires much more facilities and paved the way for the entry of E-Learning system. Now it is high time to know how these population are utilizing and exploring the changes in the learning system.

\subsection{How they assess the instructor in both models}

As web technology is to be mature and widely applied, learning resource can be realized through a wide range of publishing and sharing through internet. At the same time, various learning management systems also provide the production and publishing function for the learning resources [30]. A well designed assessment system and its effective implementation will certainly encourage students to enculture deep learning and information processing on part of themselves. When discussing about assessment, Biggs cautiously reminds that all teaching learning activities and assessment have to be parallel with learning objectives and learning outcomes [31], [32]. Learning happens well in both Traditional and Electronic learning systems but the effectiveness lies with the learner? Or it involves the instructor also? Yes, the instructor plays an important role in disseminating and motivating the students, but quality of the instructor is assessed through the performance of the learners. The results were discussed in the analysis.

\subsection{Statistical Report on USA and India on the platform of E-learning}

The US plays a leading role on e-learning in the world. The study shows that while $56 \%$ of current students are enrolled in an entirely classroom based learning system, 39\% taking at least some online courses and 5\% completely online. In five years from 2009 , only $19 \%$ of them are likely to be enrolled in an entirely classroom based learning system with $68 \%$ taking at least some online courses and $13 \%$ completely online. This means the total number of 
online learner in US has dramatically increased from 12 million to 22 million over that five year period [33][34]. Technology may well be the answer to all the ills that are currently plaguing the Indian education system. From dealing with inadequacies in India's infrastructure for delivery of education to lack of quality teachers, technology can help bridge the gap effectively. All that is needed is to integrate technology with the classrooms and teachers. Doing so will not only help address the issue of quality of instruction, but use of technology. And e-learning will also allow quality teachers to expand their reach. The education sector presents huge opportunities for private participation. According to Census figures, over $32 \%$ of the 1.1 billion populations is between the age group of $0-14$. India is fast emerging as a knowledge-based economy, and human capital has now become its major strength. This has brought to light severe inadequacies in India's infrastructure for delivery of education. It helps that India is full of young people who possess a high comfort level with technology. The population in the age-group of 15 34 increased from 353 million in 2001 to 430 million in 2011 and is predicted to grow to 464 million by 2021(Source: Report by IRIS Knowledge Foundation) Online tutoring will definitely pose a threat to conventional methods of teaching-while online learning can never look at completely replacing schools as schools offer much more than just academic knowledge inside their campuses. However, tuition centres will have to re-look at their business model and adopt digital learning aids to sharpen their offerings [35].

\section{Observation and Analysis}

Table 1. Table showing Face to face recognition of learners

\begin{tabular}{|c|c|c|}
\hline Factors & $\begin{array}{l}\text { T-Learning } \\
\text { Applicabilit } \\
\text { y }\end{array}$ & $\begin{array}{l}\text { E-Learning } \\
\text { Applicability }\end{array}$ \\
\hline $\begin{array}{l}\text { Face to } \\
\text { Recognition } \\
\text { learners }\end{array}$ & Yes & $\begin{array}{l}\text { Partially } \\
\text { Applicable }\end{array}$ \\
\hline \multicolumn{3}{|c|}{$\begin{array}{l}\text { As per Table } 1 \text {, in T-Learning observation can be } \\
\text { done with learner's weather they are in a position } \\
\text { to learn the things or not can be measured. In E- } \\
\text { Learning Time factor is fixed and that much time } \\
\text { factor can't be measured on facial expression. As } \\
\text { per the analysis it reveals that } 69.7 \% \text { of the } \\
\text { respondents agree that the face to face recognition } \\
\text { is possible in T-Learning. Enhancing instruction } \\
\text { with web component emphasizes active learning } \\
\text { bringing together the online and face-to-face } \\
\text { classroom components that could provide } \\
\text { educational highly conducive to student learning } \\
\text { [17]. }\end{array}$} \\
\hline
\end{tabular}

Table 2. Table showing Expert Knowledge

\begin{tabular}{|c|c|c|}
\hline Expert Knowledge & Yes & Yes \\
\hline \multicolumn{3}{|c|}{$\begin{array}{l}\text { As per Table } 2 \text {, comparatively expert knowledge } \\
\text { can be judged by learners community very } \\
\text { preciously depend on the explanation, but in E- } \\
\text { Learning it's not possible for hot and sour soup } \\
\text { distribution. It is highly evident from the analysis } \\
\text { that } 78.1 \% \text { agree that expert knowledge transfer is } \\
\text { complete with T-Learning system. }\end{array}$} \\
\hline
\end{tabular}

Table 3. Table showing Communication

\begin{tabular}{|c|c|c|}
\hline Communicative & & \\
\hline \multicolumn{3}{|c|}{$\begin{array}{l}\text { As per Table } 3 \text {, oral communication is the main } \\
\text { instrument of the instructor where one to one } \\
\text { communications plays an important role which is } \\
\text { agreed by } 85.6 \% \text { of the respondents. In Higher } \\
\text { Education, technology may be either used to re- } \\
\text { enforce the prevailing practices, such as lectures, or } \\
\text { it may be used to transform and disrupt those } \\
\text { practices. Although ICT has provided a potential } \\
\text { environment for change, allowing the development } \\
\text { of new approaches regarding teaching and learning } \\
\text { there is still insufficient knowledge as the best } \\
\text { practices in Higher Education Institutions (HEI), } \\
\text { mainly concerns the use of online learning } \\
\text { environments and communication tools [36]. }\end{array}$} \\
\hline
\end{tabular}

Table 4. Table showing Knowledge Sharing

\begin{tabular}{|c|c|c|}
\hline Knowledge sharing & Yes & Yes \\
\hline \multicolumn{3}{|c|}{$\begin{array}{l}\text { As per Table } 4 \text {, In Both ways knowledge can be } \\
\text { transformed but the point of fact is T-Learning will } \\
\text { be ahead of the E-Learning System due to the } \\
\text { thought sharing process because of Live } \\
\text { discussions. And it is supported by } 58.3 \% \\
\text { respondents. Also researchers suggest that learning } \\
\text { activities must support with extra activities out of } \\
\text { classroom [37]. }\end{array}$} \\
\hline
\end{tabular}

Table 5. Table showing Individual Student Concentration

$\begin{aligned} & \text { Individual student } \\ & \text { concentration }\end{aligned}$
As per Table 5, this factor is very much important
for our global educational sustainability, since a
number of technologists can be produced
successfully. As per the study $70.4 \%$ of the
respondents supported this concept. Higher
education didactics is undergoing a process of
deep analysis in a variety of educational contexts.
The main issues being focused on are related to
learning and its transferability, and tied to the need
for stronger individual interaction between
research and didactics [21 - 22].


Table 14. Table showing Involvement Learners Measurable

\begin{tabular}{|c|c|c|}
\hline $\begin{array}{ll}\begin{array}{l}\text { Involvement } \\
\text { learners } \\
\text { measurable }\end{array} & \begin{array}{l}\text { of } \\
\text { is }\end{array} \\
\end{array}$ & Yes & NA \\
\hline \multicolumn{3}{|c|}{$\begin{array}{l}\text { As per Table } 3.14 \text {, from the study it reveals that } \\
73.4 \% \text { of the respondents agree that attention and } \\
\text { involvement of the learners can be observed and } \\
\text { measured only in T-Learning. Where as in E- } \\
\text { Learning only through video conferencing it is } \\
\text { possible with the limitation that it cannot be } \\
\text { controlled. }\end{array}$} \\
\hline
\end{tabular}

Table 15. Table showing Learners Analysis along with Projection and Exploration

\begin{tabular}{|ll|l|l|}
\hline $\begin{array}{l}\text { Learners data } \\
\text { analysis along } \\
\text { projection } \\
\text { exploration }\end{array}$ & $\begin{array}{r}\text { Yes } \\
\text { and }\end{array}$ & Yes \\
\hline
\end{tabular}

As per Table 15, learner's data analysis, projection and exploration of concepts can be addressed and discussed to motivate the learners in front of the group by the instructor is highly possible only in the T-Learning. In the study it is supported by $73.9 \%$ of the respondents. In E-Learning the competency among the learners is very little.

Table 16. Table showing Survival for Fittest

\begin{tabular}{|l|l|}
\hline $\begin{array}{l}\text { Survival for the } \\
\text { fittest }\end{array}$ & Yes NA \\
\hline As per Table 16, from the study it is found that \\
$73.5 \%$ of the respondents state that E-Learning is \\
the better system to achieve the final objective of \\
job oriented practices in the globalized \\
employment arena. In T-Learning after 8 hrs of \\
class room learning it may not be possible for job \\
oriented practices but time management, discipline \\
and cultural values can be addressed only in T- \\
Learning. \\
\hline
\end{tabular}

Table 17. Table showing Experiential Learning

\begin{tabular}{|c|c|c|}
\hline Experiential learning & Yes & NA \\
\hline $\begin{array}{l}\text { As per Table } 17,64 \text {. } \\
\text { that the knowledge } \\
\text { makes the learners to } \\
\text { improves the confider } \\
\text { them to face the real }\end{array}$ & $\begin{array}{l}1 \% \text { of } \\
\text { gaine } \\
\text { under } \\
\text { ts of } t \\
\text { orld c }\end{array}$ & $\begin{array}{l}\text { ondents agree } \\
\text { sh experience } \\
\text { concepts and } \\
\text { ers which help }\end{array}$ \\
\hline
\end{tabular}

Table 19. Table showing Learners Series

\section{\begin{tabular}{|l|l|l}
\hline Learners Time Series & Yes & Yes \\
\hline
\end{tabular}}

As per Table 19, class room sessions are time bound, the learners are forced to do the activities and motivated to execute the tasks within the stipulated time, where as in E-Learning the learners have the flexibility and there is no motivation.
Hence from the study it is observed that $79.5 \%$ of the respondents say T-Learning is more effective in time utilization.

Table 20. Table showing Evaluation

\begin{tabular}{|c|c|c|}
\hline Evaluation & Yes & $\begin{array}{l}\text { Partial } \\
\text { applicable }\end{array}$ \\
\hline \multicolumn{3}{|c|}{$\begin{array}{l}\text { As per Table } 20 \text {, it is a known fact and observed } \\
\text { truth that, evaluation is more effective with } \\
\text { physical evidences. It is also observed from the } \\
\text { study that } 73.4 \% \text { of the respondents agree that the } \\
\text { assessment will be appropriate only in T-Learning. } \\
\text { This is the major phenomena for the survival of } \\
\text { educational institutions worldwide. In case of } \\
\text { "traditional teaching", the students had the } \\
\text { opportunity to attend lectures and tutorials [41]. }\end{array}$} \\
\hline
\end{tabular}

\section{Conclusion}

Literacy, in any part of the world needs to be improved to have higher growth in the economy. Educational systems requires modifications to fulfill the needs of the populations, though the availability of traditional learning and e-learning these two satisfied the needs, the competition among these two factors is also increasing higher education needs a revamping to encourage the younger generations to upgrade their qualifications and caliber. As more of the graduates seek for jobs after their under graduation the e-learning environment helps them to acquire more knowledge. Is this a threat for $\mathrm{T}$ Learning? More number of studies needs to be conducted to have clarity in this field.

The current study conducted by the researcher to understand the student's perception and preferences in the Coimbatore region. The analysis reveals that the traditional learning system has more positive attractions where the personal care and more positive relationship needs to be maintained between the instructor and the learner where as when it comes to knowledge sharing and information access the preference towards E-Learning it clearly reveals that though the instructors / teachers have enough knowledge in the subject they fail to transfer that to the students of this generation. The availability of information in the small box also plays an important role for this environment. The instructors take the role as a facilitators rather than the teacher, the time also plays a very important role for the growth of ELearning.

Though the numbers of institutions grow rapidly lot of seats remain vacant due to the factor that the knowledge transmission is not effective as expected by the student community, where as the employed youth have a wide arena in this technological world through internet and more number of courses also available online. The lack of personal relationship in this E-Learning system makes the students 
knowledgeable but it deteriorates the personal character and attitudes, which is serious threat for the society in future. As for as this research is concerned the researcher clearly states that the instructor and technology, though are two terms, should have hand shake and go in hand in order to Synchronize and last long. In case of removal of any one term the educational industry will be at stake on the knowledge transmission part. So the researcher suggest that a more effective system need to be developed with the combination of instructor, technology and learner's attitudes in order to improve the dynamic responsive system in the learning system [24]. However, the current world has been constantly evolving with information technology. Consequently, adjustments have to be made to the traditional educational model to meet the new challenges. The key of e-learning is the use of information and communication technologies on education. The main feature of e-leaning is that is comprised of all forms of electronically supported learning and teaching [1]. From the study the researcher found that a new model needs to be devised to strengthen the traditional learning system where the teachers need to be trained in knowledge sharing in the class room with available technologies where in us personal care and the knowledge sharing can be enhanced to create the positive note for the younger generation. The e-learning system cannot be avoided but can be utilized progressively by the instructors for better knowledge sharing. The more vulnerable student community, if attracted towards the traditional learning system any country will have a healthier environment economic growth and peaceful society. If the websites provide the service in enrolling students in the higher education, providing e-learning materials and other learning resources during the entire course span then many students will be attracted to enroll in higher education through e-learning [42]. Some of the techniques nowadays use the traditional classroom and most of the institutions would provide the technology and prefer to put the e-learning methods inside the traditional classroom with the hope of engaging the students with the lesson taught and to ensure that the facts delivered could be easily understood as compared to the previous method. But there are always a flaw in every new things introduced. It is believe that e-learning are unacceptable to some of the people who resist to change or afraid of technology [43]. The infrastructures in the existing institutions need to be enhanced with the available recent technologies to have a combination of T-Learning and E-Learning educational environment. Hence the researcher would suggest that the T-Learning cannot be replaced but has to be enhancing with E-Learning to create more dynamic and prospective educational system.

\section{References}

[1] Li, Xinagqian, Gao, Fuqing (2012). "Development Driven E-Learning Educational Model and Application in Teaching Information Technology", IERI Procedia 2 (2012) 854-858.

[2] P.E. Williams (2003). "Roles and Competencies For Distance Education Programs In Higher Education Institutions". The American Journal of Distance Education, 17(1), 45-57.

[3] Sarmanova, J., Kostolanyova, (2008). K. "Intelligent Individualization of Study through E-Learning", Information and Communication Technologies in Education, Ostrava: University of Ostrava, 136-142. ISBN 978-80-7368-577-5.

[4]DavidRashty,www.researchtrail.com/articles/Traditiona 1_Learning_vs_eLearning.pdf Traditional learning vs. Elearning.

[5] Hisham Barakat Hussein, "Assessing Elearning Teaching Quality of Faculty Members in Teachers' College at King Saud University: Students Perspective", at International Conference on New Horizons in Education INTE2012 published in Procedia-Social and Behavioral Sciences 55 (2012) 945-952.

[6] A. Senthil Karthick Kumar, Zubair Rahman, (2014). "Is E-Learning a Menace for T-Learning: An Analytical Report", Canadian International Conference on Education, June 16th-19th 2014, Proceedings Published by Infonomics Society, ISBN 978-1-908320-24-7, Page no: 454-459

[7] Sammour, G.N. (2009). "Elearning systems based in the semantic web", international journal of emerging technologies in learning, $v(1) \mathrm{n}(1) \mathrm{pp}$ 1-7.

[8] Beebe, R., Vonderwell, S., \& Boboc, M. (2010). "Emerging patterns in transferring assessment practices from $\mathrm{f} 2 \mathrm{f}$ to online environments". Electronic Journal of ELearning, 8(1), 1-12.

[9] Herbert W. Marsh and Lawrence A. Roche, November 1997, "Making Students Evaluations of Teaching Effectiveness Effective", the critical Issues of Validity, Bias and Utility", American Psychologist, vol.52. No.11. 1187-1197.

[10] Cavus, N., (2011). "Investigating Mobile Devices and LMS Integration in Higher Education: Student Perspectives". Procedia Computer Science, 3, 1469-1474.

[11] Marcela Sokolova, (2011). "Analysis of the Effectiveness of Teaching with the Support of eLearning in the Course of Principles of Management I- Performance Analysis", Procedia-Social Behavioral Sciences 28(2011), 174-178.

[12] Wagner, J. (2005), Nebojme se eLearningu, Ceska skola. 
[13] Al-Karni, A; Alkarni, A; Alzahrani,S;Alshamrani, A; Alsaid, M.;Elnaggar,A;Alsaghier,A; \&Alharthi, M 2006, "Assessment of Performance of Faculty Members Project Scientific Research Deanship, King Saud University, Riyadh", Saudi Arabia.

[14] Hussein, Hisham Barakat, (2011), “Attitudes of Saudi universities faculty members towards using learning management system (jusur)", The Turkish Online Journal of Educational Technology-April 2011, Volume 10 Issue 2.

[15] Rui Neves Maderia et. al, J. Luis souse, V. Fernao Pires, Luis Esteves and O.P.Dias, "World Conference on Educational Sciences 2009",Procedia Social and Behavioral Sciences 1(2009) 2441-2448.

[16] Shabnam Bidarian, Soheila Bidarian, Amirhosein Mohammad Davoudi, "A model for application of ICT in the process of teaching and learning", International conference on Education and Educational Psychology (ICEEPSY 2011), Procedia- Social and Behavioral Science 29(2011) 1032-1041.

[17] Mustafa Caner, Ilknur Yuksel, Ilknur KECIK, “A new trend in teacher education: A web-enhanced methodology course", Akdeniz Language Studies Conference 2012, Procedia-Social and Behavioral Science 70 (2013) 18311838.

[18] Aharony, N., Bronstein, J., "A Delphi Investigation into the Future of E-Learning", 2nd World Conference on Educational Technology Researchers-WCETR2012, Procedia- Social and Behavioral Sciences, 83 (2013) 911914.

[19] Dvorackova Marketa, Kostolanyova Katerina, (2012). "Complex Model of e-learning Evaluation Focusing on Adaptive Instruction", Procedia-Social and Behavioral Sciences 47(2012), 1068-1076.

[20]Shabnam Bidarian, Sohelia Bidarian, Amirhosein Mohammad Davoudi (2011). "A Model For Application Of ICT In The Process Of Teaching And Learning", Procedia-Social and Behavioral Sciences 29, 1032-1041.

[21] Brew, A. (2003). "Teaching and research: New relationships and their implications for inquiry-based teaching and learning in higher education Higher Education Research \& Development", 22, 3-18.ProcideaSocial and Behavioral Sciences 28 (2011) 673-678.

[22] Halliwell, J. (2008). "The nexus of teaching and research: Evidence and insights from the literature". Toronto: Higher Educational Quality Council of Ontario. Procedia-Social and Behavioral Sciences 28 (2011) 673678.

[23] Tuncay Sevindik, Necmi Demirkeser, Zafer Comert (2010), "Virtual Education Environments and Web Mining", Procedia Social and Behavioral Sciences 2(2010) $5120-5124$

[24] A. Senthil Karthick kumar, Zubair Rahman and Moses Daniel. (2014). "Is E-Learning a Positive Raindrop of Cloud: A Literature Review", International Journal on
Advances in Science and Technology, ISSN: 2348-5426, PP 29-35

[25] Ebrahim Zadeh, E.(2002). "Approach is necessary to open and distance education system and the use of technology in teaching and learning process is organized", Journal of Peik Noor”, 1:8

[26] Shabnam Bidarian, Soheila Bidarian, Amirhosein Mohammad Davoudi (2011): "A Model for application of ICT in the process of teaching and learning". Procedia Social and Behavioral Science 29(2011). 1032-1041.

[27] Coffield, F., Moseley, D., Hall, E., Ecclestone, K., (2004): "Learning Styles and Pedagogy in post 16 learning: A systematic and Critical Review". London: Learning and Skills Research Centre (http://www.LSRC.ac.uk)

[28] Onur Donmez, Omer Simsek, Y.Deniz Arikan (2010): "How can we make use of learner interaction in online learning environments?" Procedia-Social and Behavioral Sciences, 9(2010), 783-787.

[29] Ifran, S., "Characteristics of Sustainable Learning and Content Management System(LCMS)", Procedia Social and Behavioral Sciences 9 (2010) 1145-1152

[30] Liu Rui, Deng Maode, "A Research on E-Learning Resources Construction Based on Semantic Web", 2012 International Conference on solid State Devices and Materials Science, Physics Procedia 25(2012) 1715-1719.

[31] Biggs, J., (2003). "Aligning Teaching and Assessment to Curriculum Objectives", Learning-Teaching Support Network Generic Centre.

[32] Biggs, J. \& Tang, C., (2007). "Teaching for Quality Learning at University: 3rd Edition. Society for Research into Higher Education \& Open University Press, New York, USA: McGraw Hill.

[33] David Nagel. Most College Students to Take Classes Online by 2014. Campus Technology, October 2009.

[34] Ambient Insight. The US Market for Self-Paced eLearning Products and Services: 2009-2014 Forecast and Analysis, 2009.

[35] Pavan Chauhan, (2014), http://www.iamwire.com/ 2014/01/e-learning-practices-shaping-face-indianeducation-system/. Posted on 18th January 2014, collected on 17th August 2014

[36] Redeeker, C. Ala-Mutka, K. Bacigalupo M, Ferrari A, Punie Y, (2009) "Learning 2.0: The Impact of Web 2.0 Innovations on Education and Training in Europe", Http://is.jrc.ec.europa.eu/pages/Learning-2.0 html.

[37] Uzunboylu, H., \& Ozdamli, F., (2011). "Teacher Perception for M-Learning: Scale Development and Teachers Perceptions". Journal of Computer Assisted Learning, doi: 10.1111/j. 1365-2729.2011.00415.x

[38] Tariq M. Khan, "An Investigation of Alternative Architectures for an Expert System Enhanced Multimedia 
Training Tool", Procedia Social and Behavioral Sciences 2(2010) 4336-4340.

[39] Gramol, K., (1995). "Interactive Multimedia for Engineering Dynamics", ASEE Conf.Proc. Anaheim, CA, June 95.

[40] Sofia B. Dias, Jose A. Diniz, (2012). "Blended Learning in Higher Education: Different needs, Different Profiles", Procedia Computer Science 14(2012), 438-446.

[41] Sokolova, M., (2011). "Comparison of the Effectiveness of Teaching with the Support of eLearning to the Effectiveness of Traditional Higher Education in the Course of Principles of Management I-Comparison of the Growth Dynamics in the Performances", Procedia-Social and Behavioral Sciences 28(2011), 179-183.

[42] Goutam P., Anirban D., Kajila B., (2011). “A Study to increase effectiveness of distance learning websites in India with special reference to the state of West Bengal to increase the present GER of higher education through incorporation of E-learning facility in better way", Procedia Social and Behavioral Sciences 15, 1535-1539.

[43] Prasanna Ramakrisnan, Yuraidza bt Yahya, Mohd Nor Hajar Hasrol, Azlan Abdul Aziz (2012). "Blended Learning: A Suitable Framework for E-Learning In Higher Education", Procedia Social and Behavioral Sciences 67, 513-526.

[44] Wijina L., Loyens S.M.M., Derou. E., (2011). "Investigating Effects of Problems-Based vs. LectureBased Learning Environments on Student Motivation", Contemporary Educational Psychology”, 36(2), 101-113. 